\title{
TINJAUAN HUKUM EKONOMI ISLAM DAN UUD 1945 TERHADAP KOPERASI PERIKANAN LAUT MINA SUMITRA INDRAMAYU
}

\author{
Didi Sukardi, Kosim dan Lia Nur Alifah \\ Fakultas Syari'ah dan Ekonomi Islam \\ Institut Agama Islam Negeri Syekh Nurjati Cirebon \\ e-mail:didisukardimubarrak@gmail.com,kosim.rusdi@gmail.com \\ danlianuralifah@gmail.com
}

\begin{abstract}
Indonesia has a sea area of 5.8 million with a coastline of $81,000 \mathrm{~km}$. Indramayu district has a coastline along $114 \mathrm{~km}$ most of the inhabitants are fisherman. Marine Fisheries Cooperative Mina Sumitra located in Karang Song Indramayu is the biggest cooperative in West Java, their achievement is very impressive due to their development and progress. Democracy economy is an economic system followed by all societies as members where the cooperative as implementation. In this research, the writer wants to know whether Marine Fisheries Cooperative Mina Sumitra has applied the cooperative's job, to prospering members specially also generally in accordance Constitution 1945 Article 33 and the review of Islamic Law or not. The used methodology data is descriptive qualitative, collecting data by using observation, interview and documentation. In conclusion, the partical of democracy economy in Marine Fisheries Cooperative Mina Sumitra about the member's welfare become main principal however they do not ignore the community's welfare to. Directly or not, the existence of Marine Fisheries Cooperative Mina Sumitra has been risen the community welfare by providing job fields.
\end{abstract}

Keywords: Democracy Economy, Community's Walfare, Cooperative.

\begin{abstract}
Abstrak
Indonesia memiliki luas laut mencapai 5,8 juta km dengan garis pantai sepanjang $81.000 \mathrm{~km}$. Kabupaten Indramayu dengan garis pantai sepanjang $114 \mathrm{~km}$ sebagian besar penduduknya berpengasilan sebagai nelayan. Koperasi Perikanan Laut Mina Sumitra yang terletak di Desa Karang Song Indramayu merupakan koperasi terbesar di Jawa Barat, kiprahnya cukup mengagumkan karena perkembangan dan kemajuannya. Ekonomi kerakyatan merupakan sistem ekonomi yang mengikutsertakan seluruh lapisan masyarakat dimana koperasi sebagai implementasinya. Dalam penelitian ini penulis ingin mengetahui apakah KPL Mina Sumitra telah melaksanakan tugas koperasi mensejahterakan anggota khususnya dan masyarakat umumnya sesuai UUD 1945 Pasal 33 dan tinjauan hukum Islam. Metodologi penulisan menggunakan deskriptif kualitatif dimana pengumpulan data melalui pengamatan, wawancara dan dokumentasi. Dari penelitian yang telah dilakukan, praktik ekonomi kerakyatan pada KPL Mina Sumitra bahwa kesejahteraan anggota menjadi prinsip utama tetapi tidak mengesampingkan kesejahteraan masyarakat sekitar. Secara langsung maupun tidak, keberadaan KPL Mina Sumitra telah meningkatkan kesejahteraan masyarakat sekitar dengan lahirnya lapangan pekerjaan baru.
\end{abstract}

Kata Kunci: Ekonomi Kerakyatan, Kesejahteraan Masyarakat, Koperasi. 


\section{PENDAHULUAN}

Masalah ekonomi senantiasa menarik
perhatian masyarakat dan individu. Berbagai penelitian telah dibuat untuk menyelesaikan masalah tersebut, walaupun begitu usaha dalam mengatasi masalah ini secara keseluruhan banyak menemui kegagalan dan sangat sedikit keberhasilan yang diperoleh. Berangkat dari kegagalan tersebut, maka mulai bermunculan berbagai ekonomi alternative, diantaranya gagasan ekonomi yang berdasarkan kerakyatan yang dikenal dengan ekonomi kerakyatan dan ekonomi berdasarkan Islam, yang dikenal sebagai ekonomi Islam. Sistem ekonomi Islam sangat melindungi kepentingan setiap warganya, baik yang kaya maupun yang miskin, dengan memberikan tanggung jawab moral terhadap si kaya untuk memperhatikan si miskin. Islam mengakui sistem hak milik pribadi secara terbatas, setiap usaha apa saja yang mengarah pada penumpukkan kekayaan yang tidak layak dalam tangan segelintir orang dicela. Sebab kekayaan hanyalah amanat yang harus disebarkan manfaatnya dengan sebaik mungkin. Ekonomi rakyat adalah sektor kegiatan ekonomi orang kecil (wong cilik) yang juga sering disebut dengan istilah ekonomi kerakyatan. Mereka adalah petani kecil, nelayan, peternak, pekebun, pengrajin, pedagang kecil dan sebagainya. Prinsip ekonomi kekrakyatan yang berdasarkan keadilan yang sangat sesuai dengan tatanan dan nilai-nilai Islam, dan ekonomi kerakyatan pun tidak bisa dipungkiri menjadi sebuah solusi untuk menuju perekonomian yang diidamkan. ${ }^{1}$ Konsep ekonomi kerakyatan adalah sebuah konsep perekonomian yang memusatkan pembangunannya pada rakyat. Konsep ini menempatkan koperasi sebagai medium

\footnotetext{
${ }^{1}$ Hindi Junaidi, "Studi Terhadap Konsep Ekonomi Kerakyatan Mohammad Hatta Menurut Perspektif Ekonomi Islam”. (Skripsi, Jurusan Muamalah Fakultas Syariah dan Ilmu Hukum UIN Sultan Syarif Kasim Riau, 2011), 37.
}

pencapaian hasil, tanpa mengesampingkan peranan pasar dan negara.

Indonesia adalah Negeri Bahari. Kalimat itulah yang sangat sering didengung-dengungkan, bahkan semenjak kita masih kecil. Lantas terbayang bagaimana jayanya nenek moyang kita menembus samudra, mengarungi lautan, memanfaatkan sumberdaya kelautan dan perikanan yang ada didalamnya. Julukan Indonesia sebagai Negara Bahari bukanlah hal yang berlebihan. Kenyataan menunjukkan, lebih dari tiga per empat wilayah negeri ini adalah perairan. Luas lautnya mencapai 5,8 juta $\mathrm{km}^{2}$ dengan garis pantai sepanjang $81.000 \mathrm{~km}$. Didalam wilayah lautan yang begitu luas, tersimpan potensi sumberdaya alam, terutama sumberdaya perikanan laut yang luar biasa, baik dari segi kuantitas maupun diversitas. Sayangnya potensi yang demikian besar tersebut belum diberdayakan secara optimal, sehingga masyarakat pesisir di Indonesia masih belum sejahtera. Padahal menurut data yang ada, 140 juta penduduk $(60 \%)$ Indonesia tinggal di wilayah pesisir, $80 \%$ diantaranya bergantung pada pemanfaatan sumber daya perikanan. ${ }^{2}$

Kabupaten Indramayu merupakan salah satu Kabupaten di Provinsi Jawa Barat memiliki wilayah pesisir dengan garis pantai sepanjang $114 \mathrm{~km}$ yang merupakan garis pantai terpanjang di Provinsi Jawa Barat. Secara umum, Kabupaten Indramayu dikenal sebagai daerah pertanian juga sebagai daerah nelayan/maritime. Lebih dari $45 \%$ produksi perikanan laut Jawa Barat dipasok dari hasil Nelayan di Kabupaten Indramayu. ${ }^{3}$ Salah satu koperasi di pedesaan yang ada karena hasil alam dan mayoritas pendapatan penduduknya sebagai nelayan

${ }^{2} \mathrm{Ika}$ Sartika, "Evaluasi Kebijakan Pemberdayaan Nelayan", Jurnal Ilmu Administrasi Negara 11:2 (Juli 2011): 111.

${ }^{3}$ Omat, "Implikasi Keberadaan PPI terhadap Pertumbuhan Kawasan Ekonomi Perikanan". (Tesis, Program Pasca Sarjana Magister Teknik Pembangunan Wilayah Universitas Diponegoro Semarang, 2008), 44. 
yang berada di masyarakat yang masih eksis yaitu Koperasi Perikanan Laut (KPL) Mina Sumitra Indramayu, dimana koperasi tersebut adalah koperasi nelayan yang mayoritas masyarakatnya bekerja sebagai nelayan. Namun, disini penulis ingin mengetahui apakah koperasi tersebut adalah koperasi sebagai perwujudan ekonomi kerakyatan sesuai dengan Undang-undang yang berlaku atau tidak? Dan bagaimana Islam memandang tentang ekonomi kerakyatan apakah sesuai dengan konsep syariah? Karena dilihat dari perkembangannya koperasi tersebut merupakan koperasi yang berhasil dan maju, patut untuk diteliti. Dari latar belakang diatas, yang menunjukkan bahwa koperasi tidak berkembang dengan baik sedangkan koperasi dijadikan soko guru perekonomian Indonesia, penulis memaparkan permasalahan yang diangkat dalam penelitian ini diantaranya: (1) Bagaimana bentuk praktik ekonomi kerakyatan di Koperasi Perikanan Laut Mina Sumitra Indramayu? (2) Bagaimana tinjauan Undang-undang Dasar 1945 Pasal 33 dan hukum ekonomi syari'ah tentang praktik ekonomi kerakyatan? (3) Bagaimana analisis praktik ekonomi kerakyatan pada Koperasi Perikanan Laut Mina Sumitra Indramayu?

\section{LITERATURE REVIEW}

Tri Puji Rahayu ${ }^{4}$ dalam disertasinya yang berjudul Relevansi Pemikiran Mohammad Hatta Di Koperasi Unit Desa Grabag Pada Era Reformasi (2013) mengutip tulisan Mohammad Hatta "perekonomian Indonesia Merdeka diatur dengan usaha bersama. Dengan maksud tidak mematikan perusahaan yang kecil-kecil yang hanya dikerjakan oleh orang-seorang saja dan tidak menyinggung keperluan umum dan

${ }^{4}$ Tri Puji Rahayu, "Relevansi Pemikiran Mohammad Hatta di Koperasi Unit Desa Grabag Pada Era Reformasi”. (Disertasi, Program Studi Pendidikan Sejarah FKIP Universitas Kristen Satya Wacana, 2013), 41-42. keperluan rakyat semuanya. Desentralisasi ekonomi dilakukan memakai koperasi". Jadi Indonesia ibarat satu taman berisi pohonpohon koperasi, yang buahnya dipungut oleh rakyat banyak. Bukan koperasi yang besaing satu sama lain mencari untung besar, melainkan bekerjasama untuk membela kebutuhan-kebutuhan rakyat semuanya dan keperluan umum lainnya.

Dian Safitri ${ }^{5}$ dalam skripsinya yang berjudul Aktivitas Mohammad Hatta mengatakan bahwa salah satu jalan untuk mencapai keadilan social ialah kooperasi, yang mewujudkan kerjasama dengan dasar tolong-menolong. Organisasi kooperasi sesuai dengan cita-cita Islam, karena Islam meletakkan tanggung jawab pada individu untuk keselamatan masyarakat selurhnya. Untuk mencapai keadilan social menurut Islam, negara hendaknya merupakan suatu selfare state (yang menjamin kemakmuran bagi semua orang). Bukan hanya kemakmuran jasmani saja, namun juga kemakmuran rohani. Kesejahteraan hidup akan tercapai apabila ada keseimbangan antara kemakmuran jasmani dan rohani.

Sugiharsono $^{6}$ dalam tulisannya yang berjudul Koperasi Membina Wirausaha Berkarakter Indonesia (2014), menyatakan bahwa karakter bangsa Indonesia yang religious diaktualisasikan dalam prinsip kerja koperasi, seperti adanya pembatasan balas jasa atas modal dan penetapan jasa kredit oleh anggota yang sekaligus sebagai pelanggannya (customer). Hal ini dimaksud untuk menghindari terjadinya "riba" dalam koperasi. Prinsip kekeluargaan (kebersamaan dan kerjasama) diaktualisasikan dalam hak kepemilikan modal perusahaan secara bersama yang dapat membawa kemajuan ekonomi masyarakat secara bersama (adil dan merata). Hal ini sesuai dengan sila ke 5

${ }^{5}$ Dian Safitri, “Aktivitas Mohammad Hatta”. (Skripsi, Prodi Pendidikan Sejarah Universitas Negeri Malang, 2013), 10.

${ }^{6}$ Sugiharsono, "Koperasi Membina Wirausaha Berkarakter Indonesia”, Jurnal Economia 10:1 (April 2014): 101. 
Pancasila "keadilan social bagi seluruh rakyat Indonesia".

Zainuddin $\mathrm{Ali}^{7}$ dalam bukunya yang berjudul Hukum Ekonomi Syariah (2009), menjelaskan bahwa ekonomi syariah dilihat dari empat sudut pandang yaitu ekonomi illahiyah, ekonomi akhlaq, ekonomi kemanusiaan dan ekonomi keseimbangan. Didalam ekonomi keseimbangan pandangan Islam terhadap hak individu dan masyarakat diletakkan dalam neraca keseimbangan yang adil. Sistem hukum ekonomi syariah mencangkup cara dan pelaksanaan kegiatan usaha yang berdasarkan prinsip syariah. Ilmu ekonomi syariah merupakan ilmu pengetahuan social yang mempelajari masalah-masalah ekonomi kerakyatan yang berdasarkan prinsip-prinsip syariah. Salah satu prinsip ekonomi syariah yaitu solidaritas sosial dimana jika seorang muslim mengalami problem kemiskinan, maka tugas kaum muslimin lainnya untuk menolong orang miskin itu.

Zaidi $\mathrm{Abdad}^{8}$ dalam bukunya yang berjudul Lembaga Perekonomian Umat di Dunia Islam (2003), memaparkan bahwa koperasi dalam Islam merupakan kelompok syirkah (kerja sama) yang istilah "koperasi" itu sendiri muncul dari dunia Barat sehingga perlu ditelaah lebih lanjut apakah sesuai dengan prinsip syariah atau tidak agar pelaksanaannya tidak menyimpang dari kaidah hukum Islam. Secara keseluruhan koperasi merupakan bentuk usaha yang Islami, dengan demikian penetapan hukun koperasi adalah sebagai hukum yang mubah, yang pada khususnya dapat dikatakan sebagai praktik muamalah, dengan mengatur hubungan-hubungan kemasyarakatan.

${ }^{7}$ Zainuddin Ali, Hukum Ekonomi Syariah (Jakarta: Sinar Grafika, 2009), 1-31.

8 Zaidi Abdad, Lembaga Perekonomian Ummat di Dunia Islam (Bandung: Angkasa, 2003), 104.

\section{METODOLOGI PENELIITIAN}

Dalam penelitian ini, penulis akan menggunakan dua metode kualitatif, menurut Bogdan dan Taylor seperti dikutip oleh Lexi J.Meleong yang dimaksud dengan pendekatan kualitatif adalah sebagai sebuah prosedur dasar penelitian yang menghasilkan data deskriptif berupa katakata tertulis atau lisan dari orang-orang dan perilaku yang diamati. ${ }^{9}$ penelitian ini ditunjang dengan library research (kepustakaan) yaitu sumber data yang berupa buku-buku atau literature yang berkaitan dengan pembahasan. ${ }^{10}$

Sumber data adalah subyek darimana data tersebut diperoleh. Dan sumber data dalam penelitian ini berupa kata-kata dan tindakan orang-orang yang diamati atau diwawancarai merupakan sumber data utama. Adapun jenis-jenis data yang penulis gunakan sebagai berikut: (1) Data primer, merupakan data yang didapat dar sumber pertama baik dari individu maupun perseorangan seperti dari hasil wawancara yang biasa dilakukan oleh peneliti. (2) Data skunder, adalah data yang diperoleh dengan jalan mempelajari dan membaca buku-buku yang berkitan dengan bidang yang ditulis dan artikel dari internet serta jurnal dan lain sebagainya yang berkitan dengan penelitian. ${ }^{11}$

Teknik pengumpulan data dilakukan oleh penulis sendiri, penulis terjun langsung ke lapangan untuk mencari sejumlah informasi yang dibutuhkan untuk melakukan observasi (pengamatan), interview (wawancara) dan dokumentasi. Ketiga teknik pengumpulan data tersebut

\footnotetext{
${ }^{9}$ Lexi J. Moleong, Metode Penelitian (Bandung: Remaja Rosdaya,1995), 1.

${ }^{10}$ Burhan Bungin, Metodologi Penelitian Sosial (Surabaya: Airlangga Universitas Press, 2001), 142.

${ }^{11}$ Wulan Sari, "Peran Koperasi Unit Desa Mina Waluya Bondet terhadap Nelayan Desa Mertasinga untuk Memenuhi Kesejahteraan dalam Perspektif Ekonomi Islam". (Skripsi, Fakultas Syariah dan Ekonomi Islam IAIN Syekh Nurjati Cirebon, 2015), 38.
} 
diharapkan dapat saling melengkapi, sehingga diperoleh informasi yang diharapkan. ${ }^{12}$

Analisis data Patton dalam Nasution $(1992)^{13}$ menjelaskan bahwa analisis data adalah proses mengatur data mengorganisasikan kedalam suatu pola, kategori dan satuan uraian dasar. Ia memberikan arti yang signifikan terhadap analisis, menjelaskan pola urutan dan mencari hubungan diantara dimensi-dimensi uraian. Data yang diperoleh dari lapangan kemudian dipaparkan dalam deskripsi hasil penelitian. Beberapa langkah yang dilakukan dalam mendeskripsikan data penelitian ini, yaitu pertama, reduksi data. Dalam reduksi data yang dilakukan peneliti dimulai dengan menulis data lapangan secara terus-menerus dalam jumlah yang banyak. Kemudian tulisan tersebut direduksi, dirangkum sesuai dengan hal-hal yang pokok untuk mencari tema atau pokoknya. Kedua, display data. Mengenai display data, merujuk pada pembuatan matrik, grafik, network, atau chart yang dapat digunakan untuk melihat gambaran secara keseluruhan atau bagian tertentu secara efektif merupakan cara efektif muntuk mengambil kesimpulan. Ketiga, verifikasi dan simpulan. Awalnya masih kabar, bias, diragukan, tetapi pada tahap berikutnya karena datanya bertambah terus, maka pada akhirnya dapat diambil simpulan yang lebih grounded. $^{14}$

\section{KONSEP DASAR}

\section{Ekonomi Kerakyatan Menurut UUD 1945 Pasal 33 dan Ekonomi Islam}

Istilah ekonomi dalam bahasa Yunani adalah "oikonomos" yang berarti urusan rumah tangga. Sedangkan kerakyatan adalah ekonomi yang mengacu pada peningkatan

\footnotetext{
${ }^{12}$ Sarnawi M. Dasim, "Implementasi Pendidikan Karakter dalam Pembelajaran Sains di Sekolah Dasar", Repository.upi.edu, (2012): 89.

${ }^{13}$ Lexi J. Moleong, Metode Penelitian, 7.

${ }^{14}$ Sarnawi M. Dasim, "Implementasi Pendidikan Karakter Dalam Pembelajaran Sains di Sekolah Dasar", 94-95.
}

kemakmuran dan kesejahteraan rakyat. ${ }^{15}$ Ekonomi kerakyatan adalah sistem ekonomi yang mengikutsertakan seluruh lapisan masyarakat dalam proses pembangunan. Sistem ekonomi kerakyatan sesuai dengan UUD 1945 adalah sistem ekonomi yang demokratis. Artinya, tujuan pencapaian kesejahteraan dalam masyarakat dilakukan dengan cara yang demokratis. ${ }^{16} \mathrm{Di}$ Indonesia landasan konseptual mengenai ekonomi terpimpin tercantum dalam Undang-Undang Dasar 1945 Pasal 33 yang merupakan dasar dari demokrasi ekonomi Indonesia yang mengacu pada pemikiran Moh. Hatta tentang ekonomi kerakyatan, karena istilah ekonomi kerakyatan memang tidak ditemukan secara eksplisit dalam UUD 1945. ${ }^{17}$ Perubahan diawali dari proses peningkatan produksi dan distribusi yang selanjutnya dapat membuka kesempatan kerja. ${ }^{18}$ Namun, secara esensial makna demokrasi ekonomi dimaksud mengacu pada definisi kata "kerakyatan" sebagaimana yang dikemukakan oleh Bung Hatta. Selain itu penggunaan kata kerakyatan pada sila keempat Pancasila dapat ditafsirkan bahwa demokrasi ekonomi adalah ekonomi kerakyatan. Dalam penjelasan pasal 33, Bung Hatta menerangkan sebagai berikut: (1) Kekeluargaan itu ialah koperasi. Azas kekeluargaan itu adalah istilah dari Taman Siswa untuk menunjukkan bagaimana guru dan murid-murid yang tianggap padanya hidup sebagai suatu keluarga. Itu pulalah hendaknya corak koperasi Indonesia. (2) Makna dikuasai oleh negara UUD 1945 pasal 33 ayat 2. Pengertian dikuasai oleh

\footnotetext{
${ }^{15}$ Kbbi.web.id

${ }^{16} \mathrm{G}$. W. Murjana Yasa, "Penanggulangan Kemiskinan Berbasis Partisipasi Masyarakat di Provinsi Bali", Jurnal Ekonomi dan Sosial INPUT 1:2 (Agustus 2008): 88-89.

${ }^{17}$ Zaenal Arifin Hoeseni, "Peran Negara dalam Pengembangan Sistem Ekonomi Kerakyatan Menurut UUD 1945", Jurnal Hukum IUS QUIA IUSTUM 3:23 (Juli 2016): 512.

${ }^{18}$ G.W. Murjana Yasa, "Penanggulangan Kemiskinan Berbasis Partisipasi Masyarakat di Provinsi Bali”, 89.
} 
negara haruslah diartikan mencakup makna penguasaan oleh negara dalam arti luas yang bersumber dan diturunkan dari konsepsi kedaulatan rakyat Indonesia atas segala sumber kekayaan "bumi, air dan kekayaan alam yang terkandung didalamnya", termasuk pula didalamnya pengertian kepemilikan public oleh kolektivitas rakyat atas sumber-sumber kekayaan dimaksud. Rakyat secara kolektif itu dikonstruksikan oleh UUD 1945 memberikan mandate kepada negara untuk mengadakan kebijakan (beleid) dan tindakan pengurusan (bestuursdaad), pengaturan (regelendaad), pengelolaan (behersdaad) dan pengawasan (toezixhthoudensdaad) untuk tujuan sebesarbesarnya kemakmuran rakyat. (3) Makna digunakan untuk sebesar-besarnya kemakmuran rakyat yang terdapat dalam pasal 33 ayat 3. (4) Makna demokrasi ekonomi yang terdapat dalam pasal 33 ayat 4: Demokrasi ekonomi menurut Hatta (1932), sebagaimana halnya demokrasi Indonesia, bersumber pada nilai demokrasi asli di desa-desa di Indonesia. Ada tidak unsur demokrasi di Indonesia: musyawarah, kemerdekaan berpendapat dan tolongmenolong. Dengan menerapkan pilar demokrasi ekonomi ini, tidak ada lagi sebagian kecil orang ataupun golongan yang menguasai kehidupan orang banyak hanya karena ia menguasai factor produksi sepeerti sekarang ini. Idealnya keperluan dan kemauan rakyat banyak yang harus menjadi pedoman perusahaan dan penghasilan, karenanya semua cabang produksi yang memberikan penghasilan besar dan mengenai hajat hidup orang banyak harus dikelola secara bersama dibawah penjagaan rakyat dengan perantara badan-badan perwakilannya. ${ }^{19}$ Beberapa prinsip dalam ekonomi kerakyatan antara lain: Strategi pembanguan yang memihak rakyat, Prinsip pedoman pembangunan atas dasar

${ }^{19}$ Zaenal Arifin Hoeseni, "Peran Negara dalam Pengembangan Sistem Ekonomi Kerakyatan Menurut UUD 1945", Jurnal Hukum IUS QUIA IUSTUM 3:23 (Juli 2016): 513. musyawarah mufakat, Prinsip keterpaduan mekanisme pembangunan antara kepentingan masyarakat local dan kepentingan nasional, Prinsip koordinasi secara lintas sektor dan lintas daerah, Prinsip pelestarian pembangunan yang diselenggarakan melalui proses pembiayaan pembangunan, pemantauan dan evaluasi yang dilaksanakan oleh rakyat. ${ }^{20}$

Secara operasional, ide ekonomi kerakyatan menaruh perhatian serius terhadap nasib perekonomian rakyat yang selama ini hampa, bisa dilihat dan dipikat namun belum dapat untuk dinikmati. Keseriusan pemerintah dalam membuat kebijakan dan para pengusaha besar untuk memberdayakan masyarakat dengan berbagai kegiatan ekonomi sehingga pemerataan ekonomi dapat terwujud dan tidak terjadi kesenjangan social dalam masyarakat. Menurut ekonomi Islam sendiri dalam menanggulangi kesenjangan social dapat dilakukan beberapa hal berikut, diantaranya: ${ }^{21}$ (1) Membangun solidaritas umat, solidaritas yang ingin dibangun oleh Islam dalam menata kegiatan ekonomi harus mengacu pada prinsip-prinsip social Islam yang dinamis pemanfaatan sumber daya yang telah diberikan oleh Allah SWT kepada manusia untuk dikelola dan dikembangkan dalam upaya meningkatkan kemaslahatan umat secara merata berdasarkan prinsip keadilan dan kebenaran. (2) Mewujudkan persaudaraan sejati. Prioritas ekonomi Islam yang sudah diperjuangkan bertujuan menggerakkan keadilan dan sekaligus menanamkan rasa persaudaraan sesuai dengan kehendak Allah SWT sehingga sumber-sumber, kekayaan digunakan demi kesejahteraan umat. Konsep ekonomi Islam menitik beratkan pada tolong menolong agar kekurangan ekonomi, apalagi jika hal itu terjadi dikarenakan

\footnotetext{
${ }^{20}$ G.W. Murjana Yasa, "Penanggulangan Kemiskinan Berbasis Partisipasi Masyarakat di Provinsi Bali”, 89.

21 Zainal Arifin, "Paradigma Ekonomi Kerakyatan dalam Perspektif Islam", Ikhtiyar 6:2 (Agustus 2008): 549-550.
} 
perilaku oleh orang tertentu yang kurang peduli terhadap keadaan yang diderita saudaranya. (3) Menghindari monopoli. Realitas menunjukkan bahwa ketimpangan ekonomi yang terjadi didalam masyarakat karena terdapat segelintir orang yang menguasai (monopoli) ekonomi. Padahal, jauh sebelum konsep ekonomi yang ditawarkan oleh para ekonom, al-Qur'an telah memberikan tuntunan yang ideal agar harta kekayaan tidak dimiliki oleh segelintir orang. Oleh karena itu, monopoli sangat bertentangan dengan konsep ekonomi Islam karena tidak memberikan kesempatan kepada pengusaha kecil untuk bangkit secara ideal. Dalam hukum ekonomi syariah, kesejahteraan social dapat dimaksimalkan jika sumber daya ekonomi juga dialokasikan sedemikian rupa, sehingga dengan pengaturan kembali keadaannya. ${ }^{22}$ Secara substansi ajakan Islam mencari harta bukan untuk monopoli seluruh sentra-sentra ekonomi, melainkan didistribusikan kepada seluruh masyarakat untuk meningkatkan kesejahteraan rakyat dan mewujudkan keadilan ekonomi. ${ }^{23}$

\section{Koperasi}

Secara etimologi kata "koperasi" berasal dari kata cooperation yang bermakna kerja sama. ${ }^{24}$ Sedangkan menurut terminology dalam Undang-undang Nomor 25 Tahun 1992 tentang perkoperasian, yaitu badan usaha yang beranggotakan orang-orang atau badan hukum koperasi dengan melandaskan kegiatannya berdasarkan prinsip koperasi sekaligus sebagai gerakan ekonomi rakyat yang berdasar atas asas kekeluargaan. ${ }^{25}$

\footnotetext{
${ }^{22}$ Suhrawadi K. Lubis dan Farid Wajdi, Hukum Ekonomi Islam (Jakarta: Sinar Grafika, 2012), 13.

${ }^{23}$ Zainal Arifin, "Paradigma Ekonomi Kerakyatan dalam Perspektif Islam", 551.

${ }^{24}$ Suhrawadi K Lubis dan Farid Wajdi, Hukum Ekonomi Islam, 132.

${ }^{25}$ Undang-Undang Nomor 25 tentang Perkoperasian, (Jakarta: Lembaran Negara, 1992), 2.
}

\section{Prinsip-prinsip Koperasi}

Koperasi melaksanakan prinsip koperasi sebagai berikut: Keanggotaan bersifat sukarela dan terbuka, pengelolaan dilakukan secara demokratis, pembagian sisa hasil usaha dilakukan secara adil sebanding dengan besarnya jasa usaha masing-masing anggota, pemberian balas jasa yang terbatas terhadap modal, kemandirian.

\section{Tujuan Koperasi}

Tujuan koperasi berdasarkan Undangundang Dasar 1945 Nomor 25 Tahun 1992 Pasal 3 tentang perkoperasian adalah memajukan anggota pada khususnya dan masyarakat pada umumnya serta ikut membangun tatanan perekonomian nasional dalam rangka mewujudkan masyarakat yang maju, adil dan makmur berdasarkan Pancasila dan Undang-undang Dasar $1945 .^{26}$

\section{Fungsi dan Peran Koperasi dalam UU} No. 25 Tahun 1992 Pasal 4

Membangun dan mengembangkan potensi serta kemampuan ekonomi anggota pada khususnya dan masyarakat pada umumnya untuk meningkatkan kesejahteraan ekonomi dan social mereka, turut serta secara aktif dalam upaya mempertinggi kualitas kehidupan manusia dan masyarakat, memperkokoh perekonomian rakyat sebagai dasar kekuatan dan ketahanan perekonomian nasional dengan koperasi sebagai sokoguru, berusaha untuk mewujudkan dan mengembangkan perekonomian nasional yang merupakan usaha bersama berdasar atas asas kekeluargaan dan demokrasi ekonomi, koperasi dapat mengurangi tingkat penganggguran, koperasi dapat mengembangkan kegiatan usaha masyarakat, koperasi dapat berperan ikut meningkatkan pendidikan rakyat, terutama pendidikan perkoperasian dan dunia usaha, koperasi dapat berjuang sebagai alat

${ }^{26}$ Eros Rosmiati, "Koperasi Sebagai Implementasi Ekonomi Kerakyatan”, Widya 29: 320, (Mei, 2012), 42. 
perjuangan ekonomi, koperasi Indonesia dapat berperan menciptakan demokrasi ekonomi, dan koperasi Indonesia berperan serta dalam membangun tatanan perekonomian nasional. ${ }^{27}$

\section{Koperasi Menurut Islam}

Dalam bahasa Arab, koperasi disebut dengan syirkah yang berarti al-ikhtilath yaitu suatu perserikatan/perkongsian. Dan secara istilah, koperasi (syirkah) adalah suatu badan usaha dalam bidang perekonomian yang memiliki keanggotaan sukarela atas dasar persamaan hak, kerja sama, dan tujuan untuk memenuhi kebutuhan para anggotanya dan masyarakat pada umumnya. ${ }^{28}$ Sebagian Ulama menyebut koperasi dengan syirkah ta'awuniyah (persekutuan tolong-menolong) yaitu suatu perjanjian kerjasama antara dua orang atau lebih, yang satu menyediakan modal usaha sedangkan pihak yang lain melakukan usaha atas dasar profit sharing menurut perjanjian. ${ }^{29}$

Operasional koperasi syari'ah menggunakan akad Syirkah Mufawadhoh yakni sebuah usaha yang didirikan secara bersama-sama oleh dua orang atau lebih, masing-masing memberikan kontribusi dana dalam porsi yang sama besar dan berpartisipasi dalam kerja dengan bobot yang sama pula. Masing-masing partner

${ }^{27}$ Lita Ayudha Ningsih, "Peran Koperasi Konsumsi Pondok Pesantren Raudhatul Ulum dalam Pemberdayaan Mayarakat Setempat (Studi Kasus di Masyarakat Desa Sakatiga Indralaya Ogan Ilir)". (Dissertasi, Universitas Islam Negeri Raden Fatah Palembang, 2016), 23-27.

${ }^{28}$ Ershad Selesa, “Analisa Kebijakan Pemerintah tentang Koperasi Syariah Ditinjau dari Perspektif Islam". (Skripsi, Konsentrasi Perbankan Syariah Program Studi Muamalat Fakultas Syariah dan Hukum Universitas Islam Negeri Syarif Hidayatullah Jakarta, 2008), 50.

${ }^{29}$ Arisman, "Peran Koperasi Jasa Keuangan Syariah Usaha Gabungan Terpadu Sidogiri dalam Meningkatkan Usaha Pedagang Pasar Baru Kecamatan Tampan Pekanbaru Ditinjau Menurut Ekonomi Islam", (Skripsi, Jurusan Ekonomi Islam Fakultas Syariah dan Hukum Universitas Islam Negeri Sultan Syarif Kasim Riau, 2015), 3. saling menanggung satu sama lain dalam hak dan kewajiban. ${ }^{30}$ Adapun landasan hukum yang dapat dijadikan dasar dalam pelaksanaan syirkah, sebagai berikut:

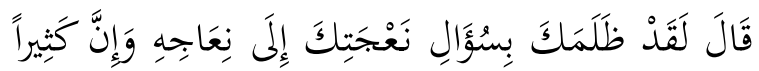

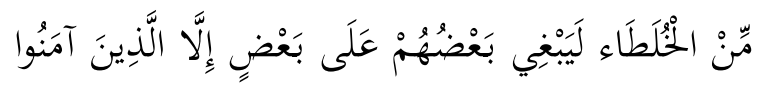

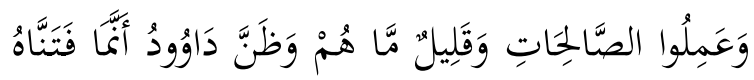

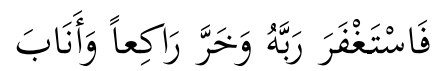

Artinya: Dia (Daud) berkata, "Sungguh, dia telah berbuat zalim kepadamu dengan meminta kambingmu itu untuk (ditambahkan) kepada kambingnya. Memang banyak di antara orang-orang yang bersekutu itu berbuat zalim kepada yang lain, kecuali orang-orang yang beriman dan mengerjakan kebajikan; dan hanya sedikitlah mereka yang begitu." Dan Daud menduga bahwa Kami Mengujinya; maka dia memohon ampunan kepada Tuhan-nya lalu menyungkur sujud dan bertaubat. ${ }^{31}$

Menurut al-Ahnaf, Koperasi dalam Islam didefinisikan Assyirkah yang berarti al-ikhtilath yaitu bercampur. Ahli fikih memberikan definisinya dengan akad antara beberapa orang mengenai suatu modal dan keuntungan. $^{32}$

${ }^{30}$ Nur S. Buchori "Koperasi Perspektif Ekonomi Syari'ah”, Mashlahah 1:1 (Juli 2010): 9394.

${ }^{31}$ QS. Shād (38): 24.

${ }^{32}$ Lita Ayudha Ningsih, "Peran Koperasi Konsumsi Pondok Pesantren Raudhatul Ulum dalam Pemberdayaan Mayarakat Setempat (Studi Kasus di Masyarakat Desa Sakatiga Indralaya Ogan Ilir)”, 21. 


\section{Al-Hadits}

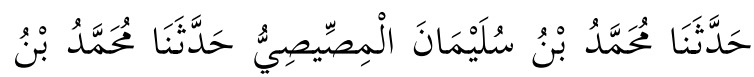

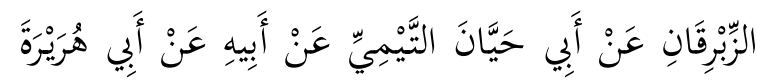

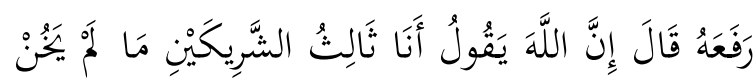

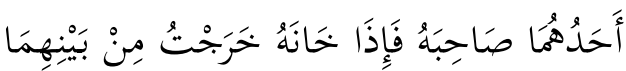
Artinya: Telah menceritakan kepada kami Muhammad bin Sulaiman Al Mishshishi, telah menceritakan kepada kami Muhammad bin Az Zibriqan, dari Abu Hayyan At Taimi, dari ayahnya dari Abu Hurairah dan ia merafa'kannya. Ia berkata; sesungguhnya Allah berfirman: 'Aku adalah pihak ketiga dari dua orang yang bersekutu, selama tidak ada salah seorang diantara mereka yang berkhianat kepada sahabatnya. Apabila ia telah mengkhianatinya, maka aku keluar dari keduanya. ${ }^{33}$

\section{Pendapat Para Ulama Mengenai Syirkah}

Terjadi perbedaan pendapat dikalangan fuqaha mengenai syirkah. 'Ulama Hanafiah membolehkan keempat syirkah yaitu syirkah 'inan, syirkah mufawwadlah, syirkah abdad dan syirkah wujuh. Sedangkan 'ulama Syafi'iyah hanya membolehkan syirkah inan saja. Sementara 'ulama Malikiah membolehkan syirkah abdad, syirkah mufawwadlah dan syirkah 'inan. Dan 'ulama Hanabilah membolehkan syirkah 'inan, syirkah wujuh dan syirkah abdad. $^{34}$

\section{Tujuan Koperasi Syari'ah}

Mensejahterakan ekonomi anggotanya sesuai norma dan moral Islam, menciptakan persaudaraan dan keadilan sesama anggotanya, pendistribusian pendapatan dan kekayaan yang merata sesama anggota

\footnotetext{
${ }^{33}$ Hadiṣ Riwayat Abū Daud Nomor 2936 dalam Bab Al-Buyu'. Lihat Abū Dawud, Sunan Abī Dawud, Beirut: Dār al-fikr, t.t.

${ }^{34}$ Muhammad Syafi'i Antonio, Bank Syari'ah Wacana Ulama dan Cendekiawan (Jakarta: BI \& Tazkia Institut, 1999), 295.
}

berdasarkan kontribusinya, membebaskan pribadi dalam kemaslahatan social yang didasarkan pada pengertian bahwa manusia diciptakan hanya untuk tunduk kepada Allah. Pengemban fungsi sosial, konsep koperasi syari'ah mengharuskan memberikan pelayanan social kepada anggota yang membutuhkannya maupun kepada masyarakat. ${ }^{35}$

\section{Keselarasan Sistem Ekonomi Indonesia dengan Konsep Dasar Ekonomi Islam}

Islam dan pacasila adalah dua realitas hidup yang berbeda tetapi sama-sama berfungsi sebagai pandangan hidup (ideology). ${ }^{36}$ Merujuk pada sila pertama, Ketuhanan Yang Maha Esa, sistem ekonomi Indonesia menekankan pada moral Pancasila yang menjunjung tinggi asas keadilan ekonomi dan keadilan social seperti halnya sistem ekonomi Islam. Tujuan sistem ekonomi Pancasila maupun sistem ekonomi Islam adalah keadilan social bagi seluruh rakayat Indonesia yang diwujudkan melalui dasardasar kemanusiaan dengan cara-cara yang rasionalistik dan demokratis, ${ }^{37}$ seperti disebutkan dalam al-Qur'an, sebagai berikut:

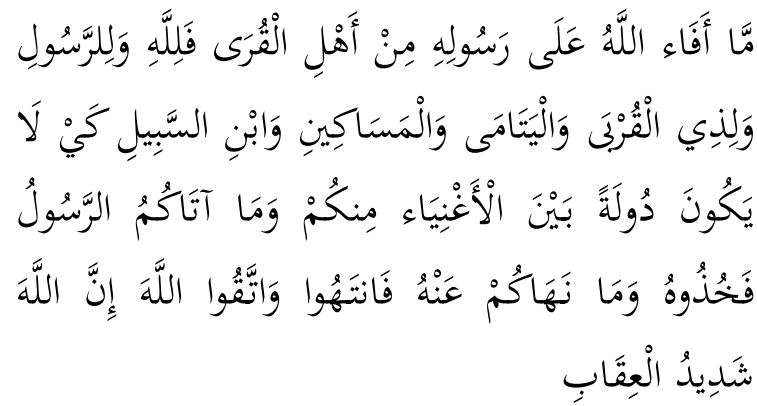

Artinya: Harta rampasan fai' yang Diberikan Allah kepada Rasul-Nya

\footnotetext{
${ }^{35}$ Nur S. Buchori "Koperasi Perspektif Ekonomi Syari'ah”, 100-102.

${ }^{36}$ Wiwin Lindayanti "Sistem Ekonomi Islam dan Sistem Ekonomi Pancasila: Studi Perbandingan Pandangan M. Chapra dan Mubyarto". (Tesis, Prodi Studi Hukum Islam Konsentrasi Keuangan dan Perbankan Syari'ah UIN Sunan Kalijaga Yogyakarta, 2007), ii.

${ }^{37}$ Yulia Hafizah, "Kebijakan Ekonomi Indonesia Ditinjau dari Konsep Dasar Ekonomi Islam”, Millah IV:2 (Januari 2005): 42-44.
} 
(yang berasal) dari penduduk beberapa negeri, adalah untuk Allah, Rasul, kerabat (Rasul), anakanak yatim, orang-orang miskin dan untuk orang-orang yang dalam perjalanan, agar harta itu jangan hanya beredar di antara orangorang kaya saja di antara kamu. Apa yang diberikan Rasul kepadamu maka terimalah. Dan apa yang dilarangnya bagimu maka tinggalkanlah. Dan bertakwalah kepada Allah. Sungguh, Allah sangat keras hukuman-Nya. ${ }^{38}$

Ekonomi Islam adalah ekonomi yang bersendikan al-Qur'an dan as-Sunnah atau ideology Islam, sementara ekonomi Indonesia yaitu ekonomi pancasila bersumber dari ideology pancasila atau turunan pancasila. Jelas letak nilai-nilai perbedaannya mengacu pada ideology masing-masing dari ekonomi Islam dan ekonomi pancasila yang dianut Indonesia. Meskipun demikian banyak pula persamaan diantara keduanya, diantaranya: (1) Kedua sistem ekonomi ini memiliki visi social dan moral. (2) Bersama-sama ingin mewujudkan keadilan dan kemerataan social bahkan jaminan social. (3) Nasionalisme ekonomi, semangat kekeluargaan, cinta mencintai dan tenggang rasa, bila sudah merata pada seluruh anggota masyarakat akan menjadikan semangat solidaritas social menuju kemerataan social. (4) Koperasi (Baitul Mal Wa Tamwil) menjadi kekuatan dalam berekonomi yang bervisi pada orangorang kecil. (5) Kesamaan dalam keseimbangan dalam implementasi kebijakan ekonomi. ${ }^{39}$ Persamaan falsafah atau etik itu ditemukan dalam penekanan pentingnya kerjasama dan tolong-menolong atau dalam Islam yaitu ta'awun,

${ }^{38}$ QS. Al-Ḥasyr (59): 7.
${ }^{39}$ Fitra Wardika, "Konsep Prof. Dr. Mubyarto tentang Ekonomi Pancasila Menurut Perspektif Ekonomi Islam", (Skripsi, Fakultas Syari'ah dan Ilmu Hukum Universitas Islam Negeri Sultan Syarif Kasim Riau, 2010), 49-51. persaudaraan (ukhuwah) dan pandangan hidup demokrasi (musyawarah). ${ }^{40}$

Deterinasi institusional badan usaha koperasi dalam perspektif yuridis konstitusional, secara esensial banyak mengandung aspek-aspek yang menjadi titik taut dengan prinsip syari'ah dalam kegiatan usaha perkoperasian. Titik temu yang dimaksud antara lain terletak pada: (1) Eksistensi badan usaha koperasi sebagai suatu konsep sistem gerakan ekonomi kerakyatan sebagai usaha bersama berdasarkan asas kekeluargaan dan demokrasi ekonomi, selain berperan dalam membangun dan mengembangkan kemampuan potensial ekonomi dan memajukan kesejahteraan anggotanya, melainkan juga berperan serta dalam mewujudkan kualitas kesejahteraan ekonomi dan social masyarakat yang maju, adil dan makmur. (2) Karakteristik badan usaha koperasi tidak sekedar menjadi persekutuan orang, melainkan sangat potensial untuk dapat dikembangkan menjadi persekutuan social dan modal. (3) Sistem pengelolaan usaha berdasarkan prinsip open management. (4) Konstruksi skim permodalan yang mengikutsertakan seluruh anggotanya sebagai pilar utama usaha pemupukan modal, selain tetap dimungkinkan skim permodalan berasal dari pinjaman dan penyertaan. (5) Sistem pemberian jasa yang terbatas terhapda modal dan sistem pembagian sisa hasil usaha yang dilakukan secara adil sebanding dengan besarnya jasa usaha masing-masing anggota. (6) Spesifikasi kegiatan usaha yang berkaitan dengan kepentingan anggota, untuk meningkatkan usaha dan kesejahteraan anggota selain tetap melakukkan layanan untuk memenuhi kebutuhan masyarakat dengan menjalankan

${ }^{40}$ Rosnani Siregar, "Peranan Koperasi dalam Meningkatkan Kesejahteraan Ekonomi Masyarakat Ditinjau dari Hukum Ekonomi Islam", at-Tijaroh 1: 1, (Januari-Juni, 2015), 237. 
kegiatan usaha di segala bidang kehidupan ekonomi rakyat. $^{41}$

Dari penjelasan diatas, maka dapat disimpulkan bahwa konsep ekonomi pancasila sejalan dengan konsep ekonomi Islam. Hal ini ditandai dengan adanya persamaan tujuan, yakni sama-sama bertujuan untuk mewujudkan keadilan social bagi seluruh rakyat Indonesia dan kemerataan social dalam kemakmuran dan kesejahteraan yang diwujudkan melalui dasar-dasar kemanusiaan dengan cara-cara yang nasionalistik dan demokratis. ${ }^{42}$

\section{PEMBAHASAN DAN DISKUSI}

\section{Ekonomi Kerakyatan Koperasi Perikanan Laut (KPL) Mina Sumitra Karang Song Indramayu}

Koperasi Perikanan Laut (KPL) Mina Sumitra Indramayu di wilayah kerja Desa Karang Song menyediakan beberapa fasilitas untuk masyarakat, diantaranya yaitu: (1) Fasilitas Bidang Kesehatan ${ }^{43}$ yaitu Balai Pengobatan yang dinamai dengan "Balai Pengobatan Mina Sumitra" Balai kesehatan melayani para nelayan, juragan dan juga untuk masyarakat umum tentunya dengan tidak dipungut biaya (gratis) bagi keluarga nelayan. (2) Fasilitas Bidang Pendidikan, adanya SMK Mitra Maritim dengan program keahlian antara lain: Nautika Kapal Penangkap Ikan (NKPI), Tehnika Kapal Penangkapan Ikan (TKPI) dan Teknologi Pengolahan Hasil Perikanan (TPHPi) dengan tidak di pungut biaya (gratis). (3) Fasilitas Bidang Sosial, program Coorporate Social Responsibility (CSR) berupa bantuan kepada madrasahmadrasah (sekolah keagamaan) yang memang membutuhkan bantuan biaya, zakat

${ }^{41}$ Ershad Selesa, "Analisa Kebijakan Pemerintah tentang Koperasi Syariah Ditinjau dari Perspektif Islam”, 50-51.

${ }^{42}$ Fitra Wardika, "Konsep Prof. Dr. Mubyarto tentang Ekonomi Pancasila Menurut Perspektif Ekonomi Islam", 51.

${ }^{43}$ Wawancara dengan Bapak H. Suryana, SE selaku Sekretaris KPL Mina Sumitra pada tanggal 16 Februari 2017 pukul 14.03 WIB. fitrah pada bulan Ramadhan. Dari berbagai kegiatan operasional KPL Mina Sumitra khususnya pada unit Pelelangan Ikan melahirkan lapangan pekerjaan baru dikalangan masyarakat sekitar seperti warung-warung kecil di sekitar tempat produksi pelelangan ikan (TPI) dan juga cator (becak motor) Secara tidak langsung, KPL Mina Sumitra telah menjalankan salah satu bentuk ekonomi kerakyatan yang dirasakan oleh masyarakat pada umumnya dalam mencapai kesejahteraan karena kegiatan operasionalnya. ${ }^{44}$

\section{Analisis Praktik Ekonomi Kerakyatan Pada Koperasi Perikanan Laut Mina Sumitra Indramayu}

Prinsip tolong-menolong, unit warung serba ada (waserda), menyediakan keperluan sembako untuk para nelayan sebelum pergi berlayar. Para nelayan yang merupakan anggota, boleh mengambil barang dengan sistem kredit. Diperbolehkan juga untuk umum. Kemudian dari unit Bahan Alat dan Perlengkapan (BAP), ${ }^{45}$ yaitu menyediakan alat berat untuk kebutuhan perlengkapan perahu seperti mesin dan jarring. Seperti halnya waserda, BAP terbuka untuk anggota dan non anggota, namun karena BAP ini menyediakan hanya perlengkapan kapal artinya pembelipun hanya para nelayan. Sistem dari BAP pun seperti waserda yaitu bisa dengan mengutang. ${ }^{46}$ Dalam Ekonomi Islam tolong-menolong (ta'awun) sangat dianjurkan, namun hanya dalam hal kebaikan. Seperti Firman Allah SWT, sebagai berikut:

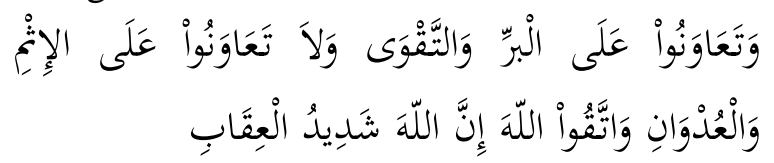

${ }^{44}$ Arif Firmansyah "Penafsiran Pasal 33 UUD 1945 dalam Membangun Perekonomian Di Indonesia", Jurnal Ilmu Hukum Syariah FH.UNISBA XIII:1 (Agustus 2012): 265.

${ }^{45}$ Wawancara dengan Bapak Slamet Jupri, SE pada tanggal 22 Maret 2017 pukul 11.43 WIB.

${ }^{46}$ Wawancara dengan Bapak Slamet Jupri, SE Unit BAP pada tanggal 17 Maret 2017 pukul 11.43 WIB. 
Artinya: Dan tolong-menolonglah kamu dalam (mengerjakan) kebajikan dan takwa, dan jangan tolong-menolong dalam berbuat dosa dan permusuhan. Bertakwalah kepada Allah, sungguh, Allah sangat berat siksa-Nya.

Dengan memberikan kemudahan dalam memenuhi kebutuhan nelayan dan membantu nelayan baik anggota maupun non anggota merupakan salah satu bentuk dalam tolong-menolong dan prinsip koperasi sebagai elemen ekonomi kemasyarakatan tidak pandang bulu, masyarakat semua berhak untuk mendapat pertolongan.

Prinsip Kerja Sama, KPL Mina Sumitra bekerja sama dengan Dinas Perikanan. Kerja sama ini diadakan selain karena ikatan dinas, juga bermanfaat dalam menjalankan tugasnya masing-masing. Kerja sama dengan para anggota yang terjalin dengan baik juga mempengaruhi perkembangan dan kemajuan KPL Mina Sumitra.

Prinsip Persaudaraan, koperasi mengenal azas kekeluargaan, namun seperti penjelasan UUD 1945 Pasal 33 Ayat (1) diatas, bahwasannya azas kekeluargaan jangan sampai salah ditafsirkan menjadi sistem kekeluargaan (family system) yang mengandung konotasi yang negative. Dalam Islam, persaudaraan (ukhuwah) itu sangat penting dalam kehidupan bermasyarakat, membangun tali silaturrahmi sesama muslim sangat diajurkan dalam Islam, seperti disebutkan dalam al-Qur'an sebagai berikut:

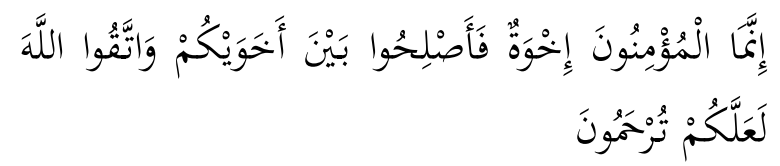

Artinya: Sesungguhnya orangorang Mukmin itu bersaudara, karena itu damaikanlah antara kedua saudaramu (yang berselisih)

\footnotetext{
${ }^{47}$ QS. Al-Maidah (5): 2.
}

dan bertakwalah kepada Allah agar kamu mendapat rahmat. ${ }^{48}$

Kehidupan bermasyarakat tentu didalamnya mengandung unsur ekonomi. Dimana jika kita saling merangkul, saling membantu satu sama lain. Karena tujuan koperasi memang untuk mensejahterakan masyarakat.

Melalui Prinsip Musyawarah, koperasi mengadakan Rapat Anggota Tahunan (RAT) di mana dalam pelaksanaan RAT tersebut para anggota dan pengurus saling bermusyawarah membicarakan mengenai program kerja yang telah dilaksanakan dalam satu periode terakhir dan yang akan dilaksanakan dalam satu periode kedepan dan juga mengevaluasi kinerja KPL Mina Sumitra dalam satu periode terakhir agar lebih baik dalam melayani masyarakat. Dalam bermusyawarah setiap orang memiliki hak yang sama, tidak ada berat sebelah dan diskriminasi. Prinsip Islam yaitu diantara kerja sama dengan musyawarah mencerminkan adanya persaudaraan (ukhuwah) yang menjadi ciri ideal ekonomi Islam seperti dalam Firman Allah SWT alQur'an surat Ali-Imran (3) ayat 159:

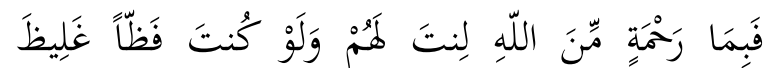

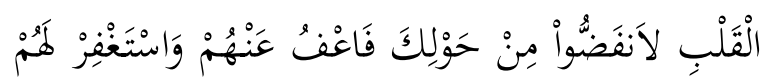

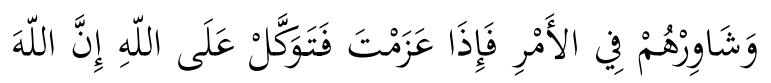

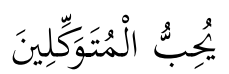
Artinya: Maka karena Rahmat dari Allah-lah, kamu pun berlaku lemah lembut terhadap mereka. Sekiranya kamu bersikap keras lagi berhati kasar, pastilah mereka menjauhkan diri dari sekelilingmu. Oleh karena itu, maafkanlah mereka, mohonkanlah ampunan bagi mereka, dan bermusyawarahlah dengan mereka dalam urusan itu. Lalu apabila kamu telah membulatkan

\footnotetext{
${ }^{48}$ QS. Al-Hujurāt (49): 10.
} 


\section{tekad, maka bertawakallah kepada Allah. Sesungguhnya Allah Mencintai orang-orang yang bertawakal. $^{49}$}

Kesejahteraan akan terwujud jika keadilan diterapkan dalam masyarakat. Keadilan merupakan pembagian yang merata kepada masyarakat, tidak memandang kasta. Sebagai koperasi, KPL Mina Sumitra telah mencoba untuk mensejahterakan masyarakat sekitar wilayah kerja. Menurutnya, dengan terciptanya lapangan kerja baru baik langsung maupun tidak langsung telah meningkatkan taraf kehidupan yang lebih baik dalam masyarakat desa Karangsong. Dalam ekonomi Islam, ekonomi berfokus pada penciptaan keadilan ekonomi. Islam mendorong terjadinya pertumbuhan ekonomi tersebut harus merata dan adil, tidak ada kesenjangan. Seperti dalam Firman Allah SWT:

وَابْتَغ فِيمَا آتَاكَ اللَّهُ اللَّارَ الْآخِخرَة وَلَا تَنَسَ نَصِيبَكَكَ مِنَ

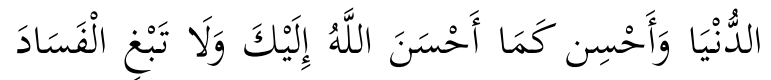

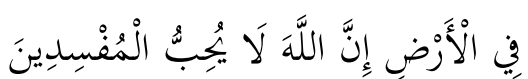

Artinya: Dan carilah (pahala) negeri akhirat dengan apa yang telah Dianugerahkan Allah kepadamu, tetapi janganlah kamu lupakan bagianmu di dunia dan berbuat baiklah (kepada orang lain) sebagaimana Allah telah Berbuat baik kepadamu, dan janganlah kamu berbuat kerusakan di bumi. Sungguh, Allah tidak menyukai orang yang berbuat kerusakan. ${ }^{50}$

Islam menganjurkan agar kehidupan manusia seimbang antara dunia dan akhirat. Sehingga dapat mencapai keadilan menuju masyarakat yang sejahtera.

\section{KESIMPULAN}

Dari pemaparan di atas, diambil 3 (tiga) kesimpulan, yaitu pertama, ekonomi kerakyatan yang telah diaplikasikan oleh KPL Mina Sumitra antara lain dalam bidang kesehatan terdapat klinik kesehatan untuk anggota dan masyarakat umum, tentunya untuk anggota tidak dipungut biaya (gratis), bidang pendidikan KPL Mina Sumitra telah mendirikan lembaga pendidikan yang akan beroperasi pada tahun ajaran 2017-2018 tanpa dipungut biaya pendidikan yaitu SMK Mitra Maritim dan dalam bidang social KPL Mina Sumitra menyediakan anggaran untuk madrasah-madrasah (sekolah keagamaan) yang mengajukan proposal bantuan dana, zakat fitrah setiap tahunnya, juga melahirkan beberapa lapangan pekerjaan baru secara tidak langsung seperti warungwarung kecil di sekitar tempat operasional, dan jasa transportasi cator.

Kedua, konsep ekonomi kerakyatan sendiri menurut Undang-undang Dasar 1945 Pasal 33 dan Hukum Ekonomi Syari'ah pada prinsipnya yaitu ekonomi kerakyatan menyangkut semua lapisan masyarakat, mulai dari yang kecil hingga besar, tidak ada diskriminasi bahkan kesenjangan social. Dimana ekonomi yang bercita-citakan keadilan sebagai perwujudan pembagian yang merata untuk kesejahteraan masyarakat Indonesia dimana itu sudah menjadi idealisme ekonomi Islam.

Dan ketiga, pada KPL Mina Sumitra hasil penelitian ekonomi kerakyatan menggunakakn prinsip koperasi yaitu prinsip tolong-menolong, prinsip kerja sama, prinsip persaudaraan (kekeluargaan), prinsip musyawarah sehingga terciptanya keadilan untuk kesejahteraan masyarakat.

\footnotetext{
${ }^{49}$ QS. 'Āli-Imrān (3): 159.

${ }^{50}$ QS. Al-Qașas (28): 77.
} 


\section{DAFTAR PUSTAKA}

Abdad, Zaidi. Lembaga Perekonomian Ummat di Dunia Islam. Bandung: Angkasa, 2003.

Ali, Zainuddin. Hukum Ekonomi Syariah. Jakarta: Sinar Grafika, 2009.

Antonio, Muhammad Syafi'i. Bank Syari'ah Wacana Ulama dan Cendekiawan. Jakarta: BI \& Tazkia Institut, 1999.

Arifin, Zainal. "Paradigma Ekonomi Kerakyatan Dalam Perspektif Islam". Ikhtiyar 6:2 (Mei-Agustus 2008).

Arisman. "Peran Koperasi Jasa Keuangan Syariah Usaha Gabungan Terpadu Sidogiri dalam Meningkatkan Usaha Pedagang Pasar Baru Kecamatan Tampan Pekanbaru Ditinjau Menurut Ekonomi Islam". Skripsi, Jurusan Ekonomi Islam Fakultas Syariah dan Hukum Universitas Islam Negeri Sultan Syarif Kasim Riau, 2015.

Buchori, Nur S. "Koperasi Perspektif Ekonomi Syari'ah". Mashlahah 1:1 (Juli 2010).

Bungin, Burhan. Metodologi Penelitian Sosial. Surabaya: Airlangga Universitas Press, 2001.

Dasim, Sarnawi M. "Implementasi Pendidikan Karakter dalam Pembelajaran Sains di Sekolah Dasar", 94-95.

Firmamsyah, Arif. "Penafsiran Pasal 33 UUD 1945 dalam Membangun Perekonomian di Indonesia”. Jurnal Ilmu Hukum Syariah FH.UNISBA XIII:1 (Agustus 2012).

Hadis Riwayat Abū Daud Nomor 2936 Dalam Bab Al-Buyū'. Lihat Abū Dawud, Sunan Abì Dawud, Beirut: Dār a1-fikr, t.t.

Hafizah, Yulia. "Kebijakan Ekonomi Indonesia Ditinjau dari Konsep Dasar Ekonomi Islam". Millah IV:2 (Januari 2005).

Hoeseni, Zaenal Arifin. "Peran Negara dalam Pengembangan Sistem Ekonomi Kerakyatan Menurut UUD
1945". Jurnal Hukum IUS QUIA IUSTUM 3:23 (Juli 2016).

Junaidi, Hindi. "Studi Terhadap Konsep Ekonomi Kerakyatan Mohammad Hatta Menurut Perspektif Ekonomi Islam". Skripsi, Jurusan Muamalah Fakultas Syariah dan Ilmu Hukum UIN Sultan Syarif Kasim Riau, 2011.

Kbbi.web.id

Lexi J. Moleong, Metode Penelitian, 7.

Lindayanti, Wiwin. "Sistem Ekonomi Islam dan Sistem Ekonomi Pancasila: Studi Perbandingan Pandangan $M$. Chapra dan Mubyarto". Tesis, Prodi Studi Hukum Islam Konsentrasi Keuangan dan Perbankan Syari'ah UIN Sunan Kalijaga Yogyakarta, 2007.

Lubis, Suhrawadi K. dan Farid Wajdi, Hukum Ekonomi Islam. Jakarta: Sinar Grafika, 2012.

Moleong, Lexi J. Metode Penelitian. Bandung: Remaja Rosdaya,1995.

Ningsih, Lita Ayudha. "Peran Koperasi Konsumsi Pondok Pesantren Raudhatul Ulum dalam Pemberdayaan Mayarakat Setempat (Studi Kasus di Masyarakat Desa Sakatiga Indralaya Ogan Ilir)". Dissertasi, Universitas Islam Negeri Raden Fatah Palembang, 2016.

Omat. "Implikasi Keberadaan PPI terhadap Pertumbuhan Kawasan Ekonomi Perikanan". Tesis, Program Pasca Sarjana Magister Teknik Pembangunan Wilayah Universitas Diponegoro Semarang, 2008.

Rahayu, Tri Puji. "Relevansi Pemikiran Mohammad Hatta Di Koperasi Unit Desa Grabag Pada Era Reformasi”. Disertasi, Program Studi Pendidikan Sejarah FKIP Universitas Kristen Satya Wacana, 2013.

Rosmiati, Eros. "Koperasi sebagai Implementasi Ekonomi Kerakyatan". Widya 29: 320 (Mei, 2012). 
Safitri, Dian. "Aktivitas Mohammad Hatta". Skripsi, Prodi Pendidikan Sejarah Universitas Negeri Malang, 2013.

Sari, Wulan. "Peran Koperasi Unit Desa Mina Waluya Bondet terhadap Nelayan Desa Mertasinga untuk Memenuhi Kesejahteraan dalam Perspektif Ekonomi Islam". Skripsi, Fakultas Syariah dan Ekonomi Islam IAIN Syekh Nurjati Cirebon, 2015.

Sartika, Ika. "Evaluasi Kebijakan Pemberdayaan Nelayan". Jurnal Ilmu Administrasi Negara 11:2 (Juli 2011).

Selesa, Ershad. "Analisa Kebijakan Pemerintah tentang Koperasi Syariah Ditinjau dari Perspektif Islam". Skripsi, Konsentrasi Perbankan Syariah Program Studi Muamalat Fakultas Syariah dan Hukum Universitas Islam Negeri Syarif Hidayatullah Jakarta, 2008.

Siregar, Rosnani. "Peranan Koperasi dalam Meningkatkan Kesejahteraan Ekonomi Masyarakat Ditinjau dari Hukum Ekonomi Islam". At-Tijaroh 1: 1, (Januari-Juni, 2015).

Sugiharsono. "Koperasi Membina Wirausaha Berkarakter Indonesia". Jurnal Economia 10:1 (April 2014).

Undang-Undang Nomor 25 tentang Perkoperasian. Jakarta: Lembaran Negara, 1992.

Wardika, Fitra. “Konsep Prof. Dr. Mubyarto tentang Ekonomi Pancasila Menurut Perspektif Ekonomi Islam”. Skripsi, Fakultas Syari'ah dan Ilmu Hukum Universitas Islam Negeri Sultan Syarif Kasim Riau, 2010.

Yasa, G.W. Murjana Yasa. "Penanggulangan Kemiskinan Berbasis Partisipasi Masyarakat di Provinsi Bali”. Jurnal Ekonomi dan Sosial INPUT 1:2 (Agustus 2008). 